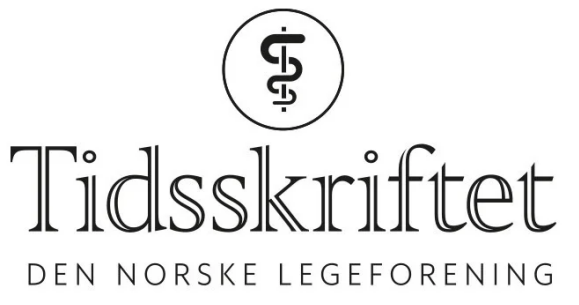

\title{
Å bytte ut salt i kosten kan gi store helsegevinster
}

FRA ANDRE TIDSSKRIFTER

TORBJØRN ØYGARD SKODVIN

Tidsskriftet

I en stor, kinesisk studie ga bytte til et saltsubstitutt færre hjerneslag, hjerteinfarkt og dødsfall. 


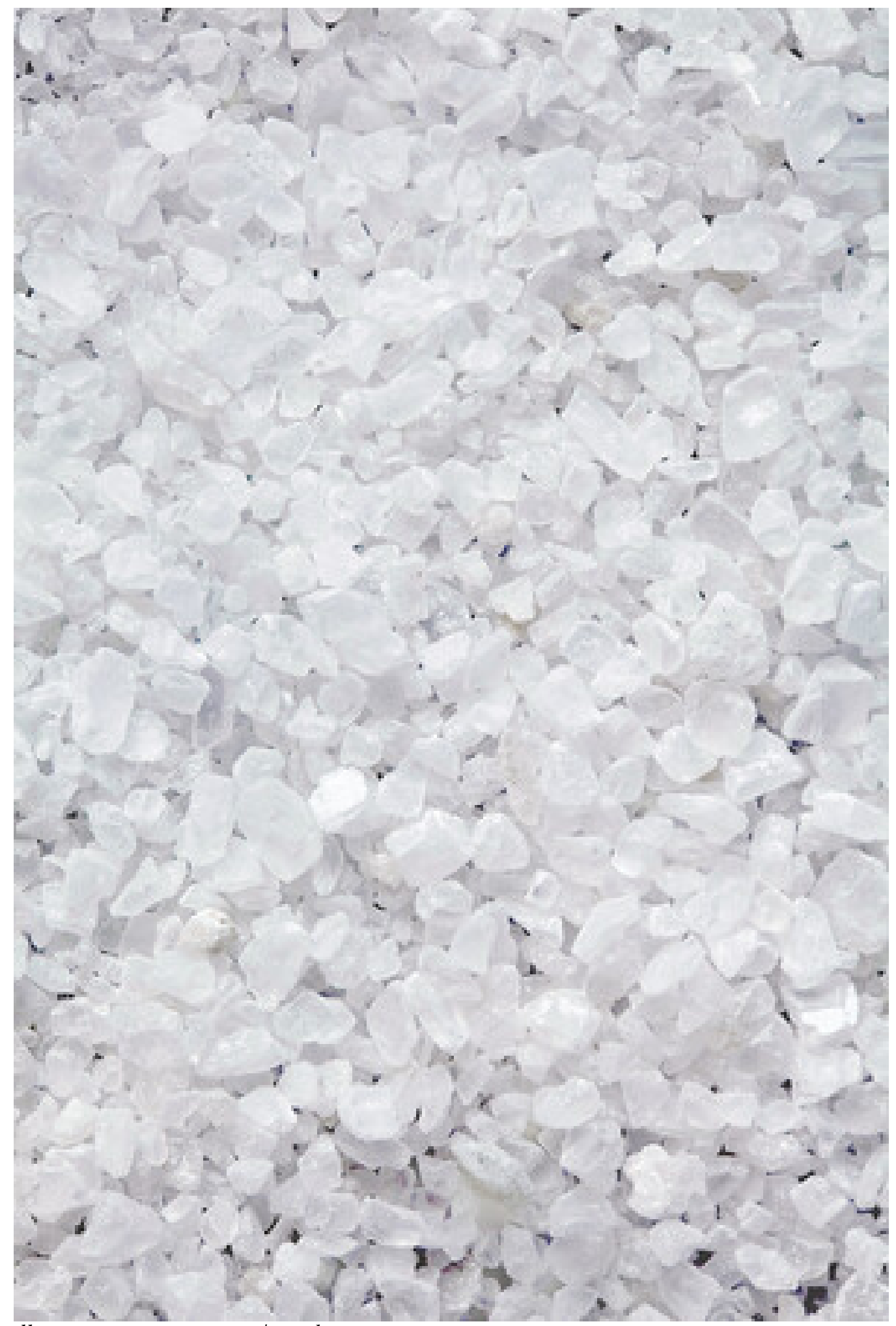

Illustrasjon: Mantonature/iStock

Høyt natriuminntak er forbundet med høyt blodtrykk, økt risiko for kardiovaskulær sykdom og prematur død. Randomiserte undersøkelser av saltsubstitutt, der noe av natriuminnholdet er byttet ut med kalium, har vist blodtrykkssenkende effekt. Kinesiske forskere har nå testet saltsubstitutt på harde kliniske endepunkter som hjerneslag, akutt koronarsyndrom og død. Studien er nylig publisert i New England Journal of Medicine (1).

I en klyngerandomisert, ikke-blind studie fikk innbyggerne i zoo kinesiske landsbyer et substitutt de skulle bruke i all matlaging i stedet for salt, mens innbyggerne i 300 andre landsbyer skulle bruke salt som vanlig. Substituttet inneholdt $75 \% \mathrm{NaCl}$ og $25 \% \mathrm{KCl}$. Studien omfattet rundt 21 ooo personer over 60 år med høyt blodtrykk eller tidligere hjerneslag. 
Insidensen av hjerneslag i løpet av oppfølgingstiden på rundt fem år (median) var signifikant lavere blant dem som fikk saltsubstitutt enn i kontrollgruppen (29 versus 34 per 1 ooo personår; insidensrateratio o,86; 95\%-KI o,77 til o,96). Insidensen av større kardiovaskulære hendelser og totaldødelighet var også signifikant lavere $(p<0,001)$. Insidensen av klinisk signifikant hyperkalemi var omtrent lik i de to gruppene $(p=0,76)$.

- Disse funnene kan være viktige for det videre folkehelsearbeidet også i Norge, men antagelig ekstra viktig i land med mindre tilgang til blodtrykksreduserende legemidler og høyere saltinntak enn i Norge, sier Hanne Løvdal Gulseth, som er fagdirektør ved Avdeling for kroniske sykdommer og aldring ved Folkehelseinstituttet.

- Saltinntaket i Norge er fremdeles høyere enn anbefalt, men gunstigere enn i mange andre land. Det er viktig å påpeke at denne studien ble gjennomført med deltagere med høyt blodtrykk og dermed høy risiko for kardiovaskulær sykdom i utgangspunktet. Det er derfor usikkert om funnene er overførbare til en generell befolkning, sier Gulseth.

\section{LITTERATUR}

1. Neal B, Wu Y, Feng X et al. Effect of salt substitution on cardiovascular events and death. N Engl J Med 2021;385: 1067-77. [PubMed][CrossRef]

Publisert: 22. november 2021. Tidsskr Nor Legeforen. DOI:10.4045/tidsskr.21.0722

(C) Tidsskrift for Den norske legeforening 2023. Lastet ned fra tidsskriftet.no 26. april 2023. 